\title{
Perbaikan Produksi Kapas (Gossypium hirsutum) Varietas Niab 999 dengan Teknik Mutasi Radiasi
}

\section{Production Improvement of Niab 999 Variety Cotton with Radiation Mutation Technique}

\author{
Lilik Harsanti, Ita Dwimahyani dan Tarmizi \\ Pusat Aplikasi Isotop dan Radiasi, BATAN \\ Jl. Lebak Bulus Raya No. 49 Jakarta 12440 \\ Email : lilik-h@batan.go.id
}

\begin{abstract}
ABSTRAK
Pemuliaan tanaman kapas perlu terus dilakukan untuk mendapatkan varietas kapas yang lebih unggul dari segi kuantitas dan kualitas. Kapas varietas NIAB 999 hasil pemuliaan yang berasal dari kultur jaringan embrio aksis kapas varietas NIAB-999 yang diradiasi dengan sinar gamma ${ }^{60}$ Co dengan dosis 20 gray. Benih kapas yang dihasilkan dari kultur jaringan $\mathrm{Kj} 1$ dan $\mathrm{Kj} 2$ dengan hasil yaitu percobaan dengan menggunakan rancangan Acak Kelompok dengan ulangan 4 kali luas plot yang berukuran 8 x $7 \mathrm{M}^{2}$ dengan jarak tanam $10 \times 100 \mathrm{~cm}$ dan menggunakan varietas Kanesia 2, Kanesia 8 dan Kanesia 9 sebagai pembanding. Pengujian jumlah buah yang terbanyak UDHP Kanesia 2 (91) dan UDHL Kanesia 2 (77). Produksi kg/ha yang tertinggi dari 6 uji multi lokasi di NTB1 Kj 2 (3740,00), Lamongan Kanesia 2 $(829,20)$, Banyuwangi Kanesia $9(982,4)$, NTB 2 Kanesia 9 (1470), Bulukumba Kanesia $9(1565,4)$, Cinangka Kanesia $9(1959,2)$ hasilnya tidak berbeda nyata, artinya sama antara kontrol nasional dan galur mutan. Penggunaan insektisida pada tanaman menyebabkan penurunan produksi kapas berbiji yaitu galur mutan $\mathrm{Kj} 1$ dan $\mathrm{Kj} 2$ sehingga galur ini lebih tinggi produktivitasnya $\mathrm{Kj} 2(857 \mathrm{~kg} / \mathrm{ha})$ dari pada yang disemprot pembasmi hama, dari tanaman kapas tidak berbeda nyata antara galur dan varietas pembanding. Galur Kj 2 dilepas sebagai varietas baru oleh Menteri Pertanian masing masing dengan nama Karisma-1 pada tahun 2009.
\end{abstract}

Kata kunci : kapas, NIAB 999, teknik mutasi, radiasi, gamma, Karisma 1

\begin{abstract}
The cotton plant breeding is necessary to improve for achive a new cotton variety with better in quality and quantity. Mutant lines of $\mathrm{Kj} 1$ and $\mathrm{Kj} 2$ derived of embryo axis in-vitro cultured of NIAB 999 cotton variety which was irradiated with gamma rays of ${ }^{60} \mathrm{Co}$ at doses of 20 Gy were used in this experiment. The experiment was conduced at NTB and designed by randomized Block design with four replications. Both mutant lines were planted in the plot with size of $8 \times 7 \mathrm{M}^{2}$ and $10 \times 100 \mathrm{~cm} 2$ spacing, Kanesia 2, Kanesia 8 and Kanesia 9 were used as control varieties. Testing of the largest number of UDHP Kanesia 2 (91) and UDHL Kanesia 2 (77). The highest production of $\mathrm{kg} / \mathrm{ha}$ from 6 multi location test in NTB1 Kj 2 (3740,00), Lamongan Kanesia 2 (829,20), Banyuwangi Kanesia $9(982,4)$, NTB 2 Kanesia 9 (1470), Bulukumba Kanesia $9(1565,4)$, Cinangka Kanesia $9(1959,2)$ the results are not significantly different from the national controls and mutant strains. The use of insecticide in the crop caused the decrease of seed cotton production, the mutant strain of $\mathrm{Kj} 1$ and $\mathrm{Kj} 2$ mutants did not need to be sprayed with pest exterminator. The result was higher productivity in $\mathrm{Kj} 2(857 \mathrm{~kg} / \mathrm{ha})$ than that sprayed with pesticide disposal. The instantaneous growth of cotton plants did not differ significantly between strains and variety varieties. Mutant line The $\mathrm{Kj} 2$ was released as new cotton varieties by Agriculture Minister by the name Karisma-1 in 2009.
\end{abstract}

Keywords : cotton, NIAB 999, mutation technique, radiation, gamma, Kharisma 1

\section{PENDAHULUAN}

Tanaman kapas (Gossypium sp.) termasuk keluarga Malvaceae, bangsa Malvales, Di
Indonesia, kapas mulai dibudidayakan secara intensif sejak kedatangan Belanda pada tahun 1596 digunakan serat sebagai untuk bahan baku tekstil dan produk tekstil serta bidang kesehatan 
dan kecantikan. Oleh karena itu kapas mempunyai peran penting dalam kehidupan dan peradaban manusia [1]. Akan tetapi ketersediaan bahan baku tersebut masih belum terpenuhi. Hal ini disebabkan oleh beberapa faktor antara lain produksi kapas rendah, petani tidak mau menanam kapas, kurang berminat dan kebutuhan kapas dalam negeri terus meningkat [2]. Hingga saat ini, Indonesia masih harus mengimpor kapas serat diatas 500 ton per tahun (lebih dari 99\%) guna memenuhi kebutuhan dalam negeri. Hal ini terjadi karena produktivitas dan produksi usaha-tani kapas menghadapi tantangan serangan hama yang serius, sehingga produktivitas dan pendapatan petani kapas masih sangat rendah dan fluktuatif. Untuk menghadapi tantangan tersebut, kajian dan pengembangan teknologi modern khususnya di bidang teknik biologi molekuler dan rekayasa genetika, berhasil membentuk kapas transgenik yang tahan atau unggul mutu serat dan produksinya, Upaya yang mungkin dilakukan untuk memperluas variasi genetik tanaman adalah hibridisasi, mutagenesis, dan induksi variasi somaklonal dalam kultur in vitro [3]

Penelitian kapas perlu dilaksanakan karena selain biaya sarana produksi masih tinggi juga ketergantungan penggunaan insektisida, umur panen lama sehingga kurang diminati petani. Pengembangan tanaman kapas dalam negeri, baik melalui program intensifikasi maupun ekstensifikasi, sangat lamban. Salah satu penyebabnya adalah adanya anggapan bahwa pada tanaman kapas terdapat banyak hama, sehingga memerlukan biaya yang besar untuk pengendaliannya, yang akhirnya berakibat pada rendahnya daya saing komoditas [4].

Kendala yang dialami dalam peningkatan produksi kapas diantaranya adalah unsur iklim, untuk itu penanaman harus didaerah penanaman tanaman kapas, jika bukan daerah penanaman tanaman kapas sering mengalami gagal panen karena air yang tersedia dalam tanah tidak mencukupi untuk pertumbuhan dan perkembangan tanaman. Selain itu petani kesulitan untuk menentukan waktu tanam yang tepat, karena hujan turun tidak menentu. Hal ini akan mengakibatkan produksi kapas tidak optimal [5]. Areal pengembangan kapas di Indonesia seperti Jawa Timur, Jawa Tengah, NTB, NTT, Sulawesi Selatan dan Sulawesi Tenggara sering mengalami hambatan karena produktivitas yang rendah. Pengembangan kapas di Indonesia diarahkan pada lahan kering, yaitu pertanian dengan penggunaan air secara terbatas atau dari air hujan. Lahan tadah hujan tersebut umumnya musim hujannya sangat pendek, yaitu hanya sekitar 3 bulan [2]. Ada beberapa faktor lain yaitu antara lain rendahnya mutu genetik dan mutu fisik benih yang digunakan dalam produksi dan kondisi lingkungan tanam. Kehilangan hasil akibat mutu benih diperkirakan mencapai $30 \%$ yang disusul oleh faktor lingkungan seperti serangan hama dan kekeringan [6].

Areal pertanaman kapas pada tahun 1985 mencapai luas 46.360 ha dengan produksi \pm 534 $\mathrm{kg} / \mathrm{ha}$ yang memberikan hasil 6,3 \% dari kebutuhan kapas dalam negeri. Setelah itu produksi terus menurun, pada tahun 1998/1999 produksi serat kapas dalam negeri tinggal 1.349 ton, yang merupakan 0,3\% kebutuhan dalam negeri. Menurut Statistik Direktorat Jendral Perkebunan Komoditas Kapas 2015, kebutuhan serat kapas sebagai bahan baku industri tekstil di Indonesia 99\% dari impor. Pada tahun 1969-2016 impor serat sebesar 474.083 ton sedangkan Ekpor sebesar 20 ton dan untuk luas areal 2.050 ha dan produktivitas 595 ton [1]. Peningkatan produktivitas kapas dapat ditempuh dengan perbaikan teknik budi daya dan penggunaan varietas unggul. Penggunaan varietas unggul merupakan komponen teknologi kunci yang mudah diadopsi petani, dan sangat menentukan keberhasilan usaha tani kapas dalam mengantisipasi kebutuhan dunia industri tekstil, arah perbaikan varietas kapas tidak hanya pada peningkatan produksi kapas berbiji tetapi juga untuk meningkatkan mutu serat dan tahan terhadap penyakit [6].

Tanaman kapas sangat membutuhkan air dari awal pertumbuhan hingga pengisian buah. Sehingga diperlukan ketersediaan varietas kapas yang berumur pendek (genjah) yang dapat dikembangkan di daerah kering, meskipun tidak tahan terhadap kekeringan varietas genjah ini dapat lolos dari kekeringan karena pada saat musim kering tiba sudah siap dipanen [5].

Ketersediaan varietas unggul yang mampu beradaptasi dengan kondisi lingkungan di Indonesia sangat diperlukan. Pemuliaan tanaman adalah ilmu pengetahuan terapan untuk memperbaiki sifat-sifat tanaman secara kualitatif dan kuantitatif yaitu usaha untuk menciptakan atau memperbesar keragaman genetik. Pemuliaan tanaman secara konvensional masih menunjukkan metode utama dalam perbaikan varietas tanaman di Indonesia. Namun demikian dengan terbatasnya 
sumber genetik (genetic resources) yang digunakan sebagai tetua dalam persilangan merupakan kendala dalam pemuliaan tanaman secara konvensional [7]. Salah satu cara untuk memperbesar keragaman genetik adalah dengan mutasi yakni suatu proses dimana gen mengalami perubahan struktur atau segala macam tipe perubahan bahan keturunan yang menyebabkan perubahan fenotip yang diwariskan dari satu ke generasi berikutnya. Dengan menggunakan mutagen atau bahan penyebab mutasi, pemulia dapat menciptakan keragaman baru dalam usaha mendapatkan varietas unggul sesuai dengan tujuan pemuliaan [8]. Dengan teknik mutasi salah satu sifat dari suatu varietas dapat diperbaiki tanpa merubah sifat yang lain. Pemuliaan mutasi sangat bermanfaat untuk perbaikan beberapa sifat tanaman saja dengan tidak merubah sebagian besar sifat tanaman asli. Pemuliaan mutasi akan lebih cepat jika perubahan karakter genetik yang diinginkan tersebut dikontrol oleh gen sederhana [9]. Mutasi induksi saat ini merupakan metode pemuliaan yang paling efektif untuk perbaikan satu atau beberapa sifat yang tidak diinginkan. Sejalan dengan ini perbaikan sifat yang diinginkan melalui metode pemuliaan mutasi mungkin berkonsentrasi hanya pada satu target [10]. Mutasi juga dapat menimbulkan sifat baru yang tidak dimiliki oleh induknya [9]. Kelebihan teknik mutasi antara lain adalah salah satu sifat dari suatu varietas dapat diperbaiki tanpa merubah sifat yang lain, menimbulkan sifat baru yang tidak dimiliki oleh induknya, dapat memisahkan pautan gen dan metode ini bersifat komplemen dengan teknik yang lain sehingga teknik tersebut dapat digunakan bersamaan dengan teknik lain seperti hibridisasi dan bioteknologi [10].

Penelitian ini bertujuan untuk memperoleh galur mutan $\mathrm{Kj} 1$ dan $\mathrm{Kj} 2$ yang dihasilkan dari program pemuliaaan mutasi pada varietas NIAB 999 yang diradiasi pada dosis 20 Gy dan galur mutan ini menunjukkan beberapa sifat lebih unggul dari induknya dan sifat lain yang adaptif pada satu lingkungan spesifik. Diharapkan galur mutan $\mathrm{Kj} 1$ dan $\mathrm{Kj} 2$ ini dapat dilepas sebagai varietas baru yang dapat menambah kasanah plasma nutfah tanaman kapas sehingga dapat menjadi pilihan untuk petani kapas di Indonesia.

\section{BAHAN DAN METODE}

\section{Prosedur pemuliaan mutasi}

Sebanyak 100 gram biji kapas dari varietas NIAB 999 yang berasal dari India dikultur media agar hingga diperoleh embrio aksis. Setelah embrio aksis berumur satu minggu diradiasi dengan sinar gamma ${ }^{60}$ Cobalt dosis 20 Gy. Embrio aksis dari biji kapas varietas NIAB 999 asal Pakistan dibiakkan pada kultur jaringan sesuai dengan prosedur yang dilakukan oleh Saeed Rauf at al 2004 Embrio aksis umur satu minggu sesudah ditanam pada media kultur jaringan diradiasi dengan sinar gamma dosis $20 \mathrm{~Gy}$.

Tanaman yang telah diaklimatisasi 2 bulan lebih di rumah kaca kemudian ditanam di polibag hingga menghasilkan buah. Tanaman kapas yang ditanam dalam polibag ini merupakan tanaman $\mathbf{M}_{1}$. Benih hasil dari tanaman $\mathbf{M}_{1}$ di bulk dan merupakan benih $\mathbf{M}_{2}$. Benih $\mathbf{M}_{2}$ ditanam di kebun percobaan Pasar Jumat untuk diseleksi terhadap sifat agronominya. Benih hasil dari seleksi ditanam sebagai galur $\mathrm{M}_{3}$ dan dimurnikan. Pemurnian galur dilakukan di kebun percobaan Pasar Jumat dan di KP. Citayam. Uji daya hasil pendahuluan dilakukan pada galur M5. Dari uji daya hasil pendahuluan terpilih dua galur harapan yaitu $\mathrm{Kj} 1$ dan $\mathrm{Kj} 2$. Selama dibudidayakan, tanaman kapas tersebut sejak dari tanaman $\mathbf{M}_{1}$ hingga seterusnya tidak di beri insektisida.

Pada galur mutan yang terpilih yaitu $\mathrm{Kj} 1$ dan Kj 2 terus dimurnikan, di Kebun Percobaan Citayam dan Pasar Jumat. Uji daya hasil pendahuluan telah dilakukan pada awal tahun 2002 KP. Citayam. Selanjutnya dilakukan uji daya hasil lanjutan pada akhir tahun 2002. Galur penelitian yang digunakan adalah 2 galur mutan : $\mathrm{Kj} 1, \mathrm{Kj} 2$ dan 2 varietas pembanding yaitu Kanesia 8 dan Kanesia 9. Pada tahun 2004 dilakukan uji daya hasil lanjutan dan daya adaptasi di Bayan NTB. Setelah galur mutan $\mathrm{Kj} 1$ dan $\mathrm{Kj} 2$ benar-benar homogen dilakukan uji multilokasi bekerja sama dengan Direktorat Jenderal Bina Produksi Perkebunan dan Balai Penelitian Tanaman Tembakau dan Serat mulai tahun 2005 hingga 2007 di 6 lokasi (di Kecamatan Bayan, Lombok Barat di NTB1 (2004), NTB2 (2006) Lamongan (2005), Banyuwangi (2006), Bulukumba (2006) dan Cinangka (2007). 


\section{Pengujian ketahanan galur terhadap hama penggerek buah (Helicoverpa armigera)}

Galur $\mathrm{Kj} 1$ dan $\mathrm{Kj} 2$ diuji ketahanannya terhadap penggerek buah kapas pada tahun 2003 di Laboratorium Hama, Balai Penelitian Tanaman Tembakau dan Serat, Malang [4]. Pengujian dilakukan dengan menggunakan rancangan acak kelompok dengan 5 perlakuan yang terdiri dari $\mathrm{Kj}$ 1, Kj 2, NIAB 999, dan Kanesia 3 dan Kanesia 7 yang merupakan varietas kontrol yang agak tahan terhadap $H$. armigera. Pengujian diulang 5 kali dan setiap ulangan diinokulasi dengan 50 ekor larva $H$. armigera yang baru menetas. Larva yang baru menetas hingga umur 2 hari diberi pakan daun, sedangkan larva yang berumur 3 hingga 8 hari diberi pakan kuncup bunga. Larva umur di atas 8 hari diberi pakan buah. Pengamatan dilakukan terhadap siklus hidup dari telur hingga imago, keperidian dan fertilitas telur dan laju pertumbuhan sesaat (r).

\section{Uji multilokasi}

Uji multilokasi pada galur $\mathrm{Kj} 1, \mathrm{Kj} 2$ dilakukan pada tahun 2005 di 6 lokasi yaitu di Jawa Timur, Jawa Barat, NTB dan Sulawesi Selatan, masing-masing adalah:

1. Bayan, NTB, pada bulan Juni 2005 - Oktober 2005.

2. Lamongan, Jawa Timur, Mei 2005 - Oktober 2005.

3. NTB, pada bulan Maret 2006 - Juli 2006.

4. Bulukumba, Sulawesi Selatan, April 2006 Agustus 2006.

5. Banyuwangi, Jawa Timur, Maret 2006 - Juli 2006.

6. Cinangka, Jakarta, Maret 2007 - Juli 2007.
Rancangan yang digunakan adalah Rancangan Acak Kelompok (RAK) dengan 5 (lima) ulangan, dengan ukuran plot: $8 \times 5 \mathrm{~m}^{2}$ dan jarak tanam 100 x $10 \mathrm{~cm}$. Pemberian pupuk dilakukan 2 kali dan 7 hari sesudah tanam (hst) dengan dosis $50 \mathrm{~kg} \mathrm{ZA}, 100 \mathrm{~kg}$ SP $36,75 \mathrm{Kg}$ $\mathrm{KCl} / \mathrm{ha}$. Pemupukan kedua berupa $100 \mathrm{~kg}$ urea/ha pada umur 42 hst. Sebagai pembanding digunakan varietas Kanesia 8 dan Kanesia 9 yang merupakan varietas unggul Nasional yang dilepas pada tahun 2003 [12]. Analisis dilakukan dengan ANOVA menggunakan program SAS.

\section{HASIL DAN PEMBAHASAN}

Penelitian perbaikan kapas dengan pemuliaan mutasi mulai dilakukan tahun anggaran 1999/2000 kombinasi teknik kultur jaringan dan teknik radiasi dilakukan pemuliaan pada varietas NIAB 999 yang berasal dari India, dengan tujuan untuk mendapatkan tanaman yang pendek, berumur genjah dan berproduksi tinggi. Banyak galur mutan yang diperoleh dari irradiasi embrio aksis NIAB 999, akan tetapi setelah melalui seleksi, terpilih dua galur mutan $\mathrm{Kj} 1$ dan $\mathrm{Kj} 2$ yang menunjukkan perbaikan sifat dari pada induknya. Galur mutan $\mathrm{Kj} 1$ dan $\mathrm{Kj} 2$ menunjukkan karakter agronomis yang berbeda dengan induknya yaitu pada tinggi tanaman dan umur panen (Tabel 1), pada galur mutan $\mathrm{Kj} 1$ dan Kj 2 panen pada umur 120 hari sedangkan pada tetuanya (NIAB 999) 140 hari; demikian juga pada varietas Kanesia 2 (140 hari) dan Galur 87002 (130 hari) yang digunakan sebagai kontrol nasional.

Tabel 1. Data agronomis pada uji daya hasil pendahuluan beberapa galur mutan kapas hasil iradiasi sinar gamma dan beberapa kultivar kontrol, Febuari kebun percobaan Citayam tahun 2002

\begin{tabular}{lllccc}
\hline No. & Genotip & \multicolumn{1}{c}{ Asal seleksi } & $\begin{array}{c}\text { Tinggi tanaman } \\
(\mathrm{cm})\end{array}$ & $\begin{array}{c}\text { Jumlah buah } \\
\text { pertanaman }\end{array}$ & $\begin{array}{c}\text { Umur panen } \\
\text { (hari) }\end{array}$ \\
\hline 1. & Ped-1 & Pedigre & 80 & 26 & 120 \\
2. & Ped-2 & Pedigre & 76 & 19 & 120 \\
3. & Ped-3 & Pedigre & 69 & 16 & 120 \\
4. & Ped-4 & Pedigre & 66 & 20 & 120 \\
5. & Kj-1 & Kultur Jaringan & 70 & 19 & 120 \\
6. & Kj-2 & Kultur Jaringan & 70 & 23 & 120 \\
7. & NIAB 999 & Varietas kontrol & 90 & 27 & 140 \\
8. & Kanesia2 & Varietas kontrol & 91 & 19 & 140 \\
9. & 870002 & Galur kontrol & 76 & 20 & 130 \\
\hline
\end{tabular}


Seperti pada umumnya, secara fisik kapas berumur genjah akan lebih pendek dan kecil dari pada yang berumur sedang. Pada Tabel 1. tinggi tanaman rata rata pada galur mutan $\mathrm{Kj} 1$ dan $\mathrm{Kj} 2$ adalah $70 \mathrm{~cm}$ sedangkan NIAB $999(90 \mathrm{~cm})$ dan Kanesia $2(91 \mathrm{~cm})$. Hasil pengamatan data sifat agronomis pada uji daya hasil lanjutan yang dilaksanakan pada bulan November 2002 menunjukkan hasil panen, tinggi tanaman dan jumlah buah pada kedua galur mutan tersebut sudah stabil. (Tabel 2) tinggi tanaman pada semua galur dan varietas yang diuji agak lebih pendek karena pada saat penanaman kurang air yang disebabkan mundurnya musim hujan, akan tetapi umur panen sudah stabil [13]. dari Pakistan dan ditanam pad musim tanam $\mathrm{Mk}$ 2014 di Kebun Percobaan Citayam. Pola tanam monokultur kapas genjah dapat ditanam dengan populasi $60.000-100.000$ tanamn/ha dan tanaman berumur sedang populasinya sekitar 40.000 tanaman/ha [3]. Populasi tanaman/ha tersebut ditentukan oleh jarak tanam dan faktor fisik lingkungan yang mempengaruhi tinggi rendahnya produksi kapas per/ha.

Pengamatan kualitatif pada sifat agronomis yang lain (bentuk bol, warna serat dan tipe pembungaan), galur mutan $\mathrm{Kj} 1$ dan $\mathrm{Kj} 2$ menunjukkan perbedaan yaitu bentuk bol/buah lebih bulat, warna serat sangat putih sehingga tidak perlu perlakuan khusus untuk memutihkan

Tabel 2. Data agronomis pada uji daya hasil lanjutan beberapa galur mutan kapas hasil iradiasi sinar gamma dan beberapa kultivar kontrol, November kebun percobaan Citayam tahun 2002

\begin{tabular}{cllccc}
\hline No. & \multicolumn{1}{c}{ Genotip } & Asal seleksi & $\begin{array}{c}\text { Tinggi tanaman } \\
(\mathrm{cm})\end{array}$ & $\begin{array}{c}\text { Jumlah buah } \\
\text { pertanaman }\end{array}$ & $\begin{array}{c}\text { Umur panen } \\
\text { (hari) }\end{array}$ \\
\hline 1. & Ped-1 & Pedigre & 73 & 13 & 120 \\
2. & Ped-2 & Pedigre & 65 & 12 & 120 \\
3. & Ped-3 & Pedigre & 63 & 12 & 120 \\
4. & Kj-1 & Kultur Jaringan & 60 & 12 & 120 \\
5. & Kj-2 & Kultur Jaringan & 53 & 12 & 120 \\
6. & NIAB 999 & Varietas kontrol & 72 & 16 & 135 \\
7. & Kanesia2 & Varietas kontrol & 77 & 16 & 140 \\
8. & 870002 & Galur kontrol & 63 & 14 & 130 \\
\hline
\end{tabular}

Penelitian tanaman kapas dengan kombinasi teknik kultur jaringan dan teknik radiasi dilakukan pada benih kapas varietas NIAB 999 yang berasal

dan pada saat buah matang merekah sempurna sehingga mudah memanen dan melepaskan dari kulit buah sehingga mempercepat waktu panen

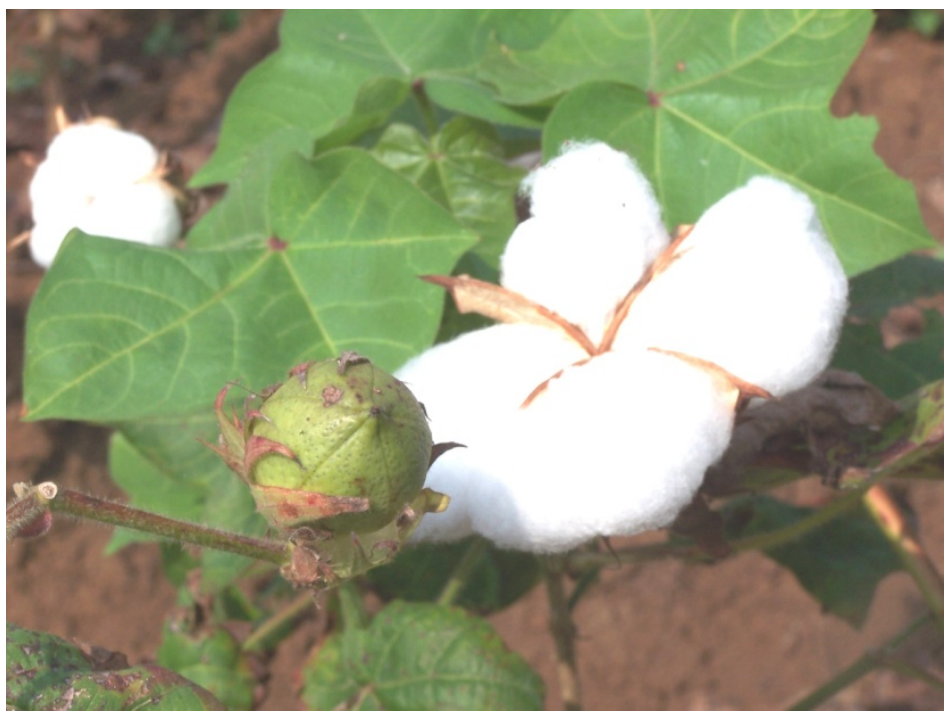

Gambar 1. Bentuk bol dan buah kapas yang sudah matang (merekah) pada galur mutan $\mathrm{Kj} 2$ 
dan menghemat tenaga pada proses pemanenan dilapangan, dengan demikian pemerosesan akan cepat dilakukan baik penjemuran kapas, membuang kapas dari biji dengan mesin Ginning dan membuang kabu kabu dari biji kapas [4]. pada masing masing uji multi lokasi penanaman kapas dan pengaruh pemberian insektisida terhadap produksi pada galur mutan kapas $\mathrm{Kj} 1$, $\mathrm{Kj}$ 2, Kanesia 8 dan Kanesia 9 dan berumur genjah (Tabel 3).

Tabel 3. Keragaman produktivitas galur-galur $\mathrm{Kj} 1$ dan $\mathrm{Kj} 2$ dan varietas Kanesia 8 dan Kanesia 9 di enam uji multilokasi

\begin{tabular}{lccccccc}
\hline \multicolumn{1}{c}{ Galur/ } & NTB1 & Lamongan & Banyuwangi & NTB2 & Bulukumba & Cinangka & $\begin{array}{c}\text { Panen } \\
\text { (Hari) }\end{array}$ \\
varietas & 2005 & 2005 & 2006 & 2006 & 2006 & 2007 & 110 \\
Kj 1 & $3499,33 \mathrm{a}$ & $787,87 \mathrm{a}$ & $927,8 \mathrm{ab}$ & $1062 \mathrm{a}$ & $1397,0 \mathrm{a}$ & $1872,6 \mathrm{a}$ & 115 \\
Kj 2 & $3740,00 \mathrm{a}$ & $761,73 \mathrm{a}$ & $832,2 \mathrm{ab}$ & $1120 \mathrm{a}$ & $1315,8 \mathrm{a}$ & $1856,4 \mathrm{a}$ & $115 \mathrm{a}$ a \\
Kans. 8 & $3739,33 \mathrm{a}$ & $768,47 \mathrm{a}$ & $672,6 \mathrm{~b}$ & $1074 \mathrm{a}$ & $1304,6 \mathrm{a}$ & $1937,4 \mathrm{a}$ & 120 \\
Kans. 9 & $3640,00 \mathrm{a}$ & $829,20 \mathrm{a}$ & $982,4 \mathrm{a}$ & $1470 \mathrm{a}$ & $1565,4 \mathrm{a}$ & $1959,2 \mathrm{a}$ & 120 \\
\hline BNT5\% & 508,21 & 274,22 & 307,18 & 451 & 294,39 & 550,62 & \\
KK $(\%)$ & 10,09 & 25,29 & 26,11 & 27,8 & 15,31 & 20,96 & \\
\hline
\end{tabular}

Tabel 4. Lama setiap stadia pertumbuhan dan siklus hidup (telurimago Helicoverpa armigera) pada beberapa galur/varietas kapas

\begin{tabular}{|c|c|c|c|c|c|}
\hline \multirow{2}{*}{ No. } & \multirow{2}{*}{$\begin{array}{c}\text { Galur/ } \\
\text { varietas }\end{array}$} & \multicolumn{3}{|c|}{ Lama stadia (hari) } & \multirow{2}{*}{$\begin{array}{l}\text { Lama siklus } \\
\text { hidup (hari) }\end{array}$} \\
\hline & & Larva & Pupa & Imago & \\
\hline 1. & $\mathrm{Kj} 1$ & $18 \mathrm{a}$ & $22 \mathrm{a}$ & $15 \mathrm{a}$ & 59 a \\
\hline 2. & $\mathrm{Kj} 2$ & $17 \mathrm{a}$ & $21 \mathrm{a}$ & $16 \mathrm{a}$ & 59 a \\
\hline 3. & Niab 999 & $18 \mathrm{a}$ & $22 \mathrm{a}$ & $14 \mathrm{a}$ & 58 a \\
\hline 4. & K3 & $19 \mathrm{a}$ & $21 \mathrm{a}$ & $13 \mathrm{a}$ & $57 \mathrm{a}$ \\
\hline 5. & K7 & $18 \mathrm{a}$ & $22 \mathrm{a}$ & $12 \mathrm{a}$ & 56 a \\
\hline
\end{tabular}

Tampak pada Gambar 1 bunga merekah dan boll atau buah kapas yang bulat sedang biji kapas dari varietas unggul kontrol nasional yaitu kanesia 8 dan kanesia 9 tampak buahnya agak lonjong lurus sehingga ada perbedaan antara galur mutan harapan kapas yaitu $\mathrm{Kj} 1$ dan $\mathrm{Kj} 2$ dan kontrol nasional

Sifat agronomis pada produksi yang tertinggi pada Tabel 3. yaitu penanaman pada enam lokasi multi lokasi penanaman kapas yaitu NTB1 tahun $2005 \mathrm{Kj} 2$ (3740.00), Lamongan tahun 2005 Kanesia $9(829,20)$, Banyuwangi tahun 2006 Kanesia $9(982,4)$, NTB2 tahun 2006 Kanesia 9 (12565,4), Bulukumba tahun 2006 Kanesia 9 (1959,2), Cinangka tahun 2007 Kanesia $9(1959,2)$ hasil nya tidak berbeda nyata dengan galur mutan harapan hanya berbeda sedikit dengan kontrol nasional.

Hasil menunjukkan bahwa pemberian insektisida tidak terlalu berpengaruh terhadap berat bol kapas yang sangat menentukan produksi
Untuk uji ketahanan galur galur mutan $\mathrm{Kj} 1$ dan $\mathrm{Kj} 2$ terhadap hama penggerek buah (Helicoverpa armigera) dilakukan di Laboratorium Hama, Balai Penelitian Tanaman Tembakau dan Serat, Malang. Siklus hidup Helicoveerpa armigera yang hidup dengan pakan yang berasal dari tanaman kapas tidak berbeda nyata antara galur dan varietas yang diuji, yaitu antara 56 - 59 hari. Varietas atau galur yang tahan terhadap Helicoverpa armigera mempunyai stadia pertumbuhan yang lebih panjang dibanding dengan varietas/galur yang peka (Tabel 4).

Jumlah telur yang dihasilkan imago $H$. armigera (keperidian) berkisar antara 702 hingga 1069 butir. Terjadi penurunan keperidian yang cukup tajam pada pemberian pakan tanaman galur Kj 1 dibandingkan tetuanya NIAB 999, yaitu dari 1069 butir menjadi 702 butir. Walaupun demikian perbedaan ini secara statistik tidak berbeda nyata (Tabel 5). 
Tabel 5. Keperidian dan fertilitas telur $H$. armigera pada beberapa galur/varietas kapas

\begin{tabular}{llcc}
\hline No. & Galur/varietas & $\begin{array}{c}\text { Keperidian } \\
\text { (butir) }\end{array}$ & $\begin{array}{c}\text { Fertilitas } \\
(\%)\end{array}$ \\
\hline 1. & Kj 1 & $702 \mathrm{a}$ & $60 \mathrm{a}$ \\
2. & Kj 2 & $919 \mathrm{a}$ & $56 \mathrm{a}$ \\
3. & NIAB 999 & $1.069 \mathrm{a}$ & $75 \mathrm{a}$ \\
4. & Kanesia 3 & $998 \mathrm{a}$ & $56 \mathrm{a}$ \\
5. & Kanesia 7 & $1.044 \mathrm{a}$ & $50 \mathrm{a}$ \\
\hline
\end{tabular}

Tabel 6 memperlihatkan laju pertumbuhan sesaat (r) H. armigera pada galur/varietas yang diuji. Laju pertumbuhan sesaat (r) merupakan salah satu variable yang digunakan sebagai ukuran ketahanan suatu tanaman. Nilai $r$ yang lebih rendah mengindikasikan tingkat ketahanan yang lebih tinggi. Seperti yang disampaikan oleh Subiyakto 2011 bahwa laju pertumbuhan sesaat Myzus persicae (Homoptera : Aphididae) pada galur tembakau yang tahan adalah lebih kecil dibanding pada galur tembakau yang peka. Galur $\mathrm{Kj} 2$ mempunyai nilai $\mathrm{r}$ yang paling rendah, yaitu 0,30 yang merupakan $64 \%$ dari nilai $\mathrm{r}$ varietas Kanesia 3 dan $52 \%$ dari nilai r varietas Kanesia 7. Galur Kj 1 mempunyai nilai r 0,38 merupakan 81 $\%$ dari nilai $r$ varietas Kanesia 3 dan $61 \%$ dari nilai $\mathrm{r}$ varietas Kanesia 7. Dari perhitungan statistik tidak berbeda nyata antara nilai $r$ galur mutan atau varietas yang diuji, sehingga semua galur dan varietas ini bersifat agak tahan terhadap $H$. armigera. Akan tetapi dilihat dari rendahnya nilai $\mathrm{r}$ pada galur mutan $\mathrm{Kj} 1$ dan $\mathrm{Kj} 2$ bila dibandingkan dengan NIAB 999 dan varietas Kanesia 3 ataupun Kanesia 7, dapat ditarik kesimpulan bahwa galur $\mathrm{Kj} 1$ dan $\mathrm{Kj} 2$ cenderung
Hama yang lain adalah hama penggerek yang menyerang tanaman kapas mulai berkecambah hingga masa panen. Hama penggerek tersebut sangat cepat menjadi resisten terhadap suatu insektisida. Beberapa negara penghasil kapas seperti Australia [14], Pakistan [11] dan Cina [16], merupakan negara subtropik yang menggunakan beberapa jenis insektisida berganti-ganti atau secara kombinasi dalam usaha membasmi hama tersebut. Satu betina dewasa dari hama penggerek menghasilkan ratusan butir telur, bahkan pada Helicoverpa armigera (Lepidoptera : Noctuidae) telur yang dihasilkannya dapat mencapai 1000 butir [15]. Di Indonesia hama penggerek mempunyai banyak musuh alami. Hal ini dimungkinkan oleh karena hanya bagian kepala dan thorax dari larva penggerek yang berada di dalam jaringan tanaman, sedangkan bagian abdomennya menjulur keluar. Varietas kapas dengan kandungan gosipol tinggi tahan terhadap serangan hama Aphididae, Miridae, Tetranychidae, dan larva penggerek buah, Heliothis dan Helicoverpa [16].

Musuh alami yang hingga saat ini telah diketahui antara lain Goniozus spp (Hymenoptera:

Tabel 6. Laju pertumbuhan sesaat (r) H. armigera pada beberapa galur/varietas kapas

\begin{tabular}{clrl}
\hline No. & \multicolumn{1}{c}{ Galur/varietas } & $\mathrm{r}$ \\
\hline 1. & $\mathrm{Kj} \mathrm{1}$ & 0,38 & $\mathrm{a}$ \\
2. & $\mathrm{Kj} \mathrm{2}$ & 0,30 & $\mathrm{a}$ \\
3. & NIAB 999 & 0,48 & $\mathrm{a}$ \\
4. & Kanesia 3 & 0,47 & $\mathrm{a}$ \\
5. & Kanesia 7 & $0,58 \mathrm{a}$ \\
\hline
\end{tabular}

mempunyai toleransi yang lebih baik terhadap hama penggerek buah $(H$. armigera) daripada tetua dan varietas pembanding lainnya.
Bethyloidea), yang bersifat membunuh atau parasit dari Pectinophora gossypiella (Lepidoptera : Gelechiidae). Bracon lefroyi (Hymenoptera : Braconidae) merupakan parasit dari larva Earias 
vitella (Lepidoptera : Noctuidae) dan $P$. gossypiella. Trichogramma minutum : (Hymenoptera : Trichogrammatidae) merupakan parasit dari telur Helicoverpa armigera. Dorylus laevigatus (Hymenoptera : Formicidae) pemakan pupa dari serangga hama, dan juga bersifat sangat karnifora terhadap serangga hama. Selenopsis geminata (Hymenoptera : Formicidae), pemakan larva serangga hama [17]. Menurut Holeay, et al. (2002), Solenosis geminata merupakan pemakan serangga hama dari ordo Hemiptera dan Lepidoptera pada stadia telur, nimfa, larva dan pupa.

Keberhasilan tanaman kapas untuk berproduksi sangat tergantung pada musuh alami dari hama penggerek sehingga pemilihan insektisida nabati maupun kimiawi pada budidaya tanaman kapas harus tepat, juga jenis insektisidanya maupun waktu pemberiannya.
Hal ini berlaku untuk semua galur dan varietas yang diuji. Di Banyuwangi satu kali penyemprotan sudah membuat square berguguran. Penggunaan insektisida pada tanaman menyebabkan penurunan produksi kapas berbiji (Tabel 3). Terlihat pada keragaman data produktivitas baik pada galur mutan $\mathrm{Kj} 1, \mathrm{Kj} 2$, maupun Kanesia 8 dan Kanesia 9 di dua lokasi yaitu Lamongan dan Banyuwangi yang menggunakan insektisida menunjukkan yang sangat rendah dibandingkan dengan penanaman dilokasi lain (NTB, Bulukumba dan Cinangka). Pada Tabel 7 yaitu perbandingan rerata produktivitas antara perlakuan dengan insektisida dan tanpa insektisida, pada galur mutan $\mathrm{Kj} 1, \mathrm{Kj} 2$, Kanesia 8 dan Kanesia 9, menunjukkan respon yang sama antara kedua perlakuan, yaitu dengan nilai produktivitas 2 kali lebih tinggi dari pada tanpa insektisida.

Tabel 7. Rerata keragaan produktivitas galur mutan $\mathrm{Kj} 1$,

$\mathrm{Kj}$ 2, Kanesia 8 dan Kanesia 9 dengan perlakuan insektisida dan tanpa perlakuan insektisida

\begin{tabular}{lcc}
\hline Galur/varietas & $\begin{array}{c}\text { Dengan insektisida } \\
(\mathrm{kg} / \mathrm{ha})\end{array}$ & $\begin{array}{c}\text { Tanpa insektisida } \\
(\mathrm{kg} / \mathrm{ha})\end{array}$ \\
\hline $\mathrm{Kj} \mathrm{1}$ & $1.957,7$ & 857,84 \\
$\mathrm{Kj} 2$ & $2.008,1$ & 796,97 \\
Kanesia 8 & $2.013,8$ & 720,54 \\
Kanesia 9 & $2.158,7$ & 905,81 \\
\hline
\end{tabular}

Masalah memilih justru akan memusnahkan predator dan musuh alami hama utama sehingga mengganggu keseimbangan ekosistem yang berakibat kerusakan pada budidaya kapas [18].

Berdasarkan asumsi tersebut diatas maka dari awal pengujian daya hasil galur mutan $\mathrm{Kj} 1$ dan $\mathrm{Kj} 2$ tidak menggunakan insektisida. Produksi kapas berbiji galur $\mathrm{Kj} 1$ dan $\mathrm{Kj} 2$ tidak menunjukan perbedaan yang nyata dibandingkan dengan varietas Kanesia 8 dan Kanesia 9 di 6 lokasi uji. Penggunaan insektisida di Lamongan pada tahun 2005 disebabkan adanya serangan Bemisia, sedangkan di Banyuwangi pada tahun 2006 hanya sebagai proteksi. Di Lamongan, penyemprotan insektisida 4 kali menyebabkan hama Bemisia musnah. Sebagai gantinya square (bakal buah tidak jadi) berguguran. Dari hasil pengamatan pada umur 70 hari setelah tanama, tidak ada satupun buah yang terbentuk, walaupun banyak bunga. Pertumbuhan vegetatifnya normal.
Menurut Efrem, (2012), pada umumnya gugurnya square (bakal buah yang tidak jadi) disebabkan oleh serangga Pectinophora gossypiella (penggerek bunga). P. gossypiella mempunyai musuh alami, diantaranya Dorylus laevigatus dan Selenopsis geminata, kedua serangga ini dikenal sebagai semut yang bersarang ditanah, berwarna coklat, dan aktif pada malam hari. Adanya serangan penggerek bunga pada tanaman yang disemprot dengan insektisida, mencegah adanya kedua jenis semut ini. Dengan tidak adanya kedua jenis semut ini membuktikan bahwa semut yang bersarang di tanah peka terhadap insektisida. Berlainan dengan $P$. Gossypiella, peka terhadap insektisida. Pada uji multilokasi di Bulukumba tahun 2006 terlihat adanya semut (Selenopsis geminata).

Penggunaan insektisida pada tanaman menyebabkan penurunan produksi kapas berbiji yaitu galur mutan $\mathrm{Kj} 1$ dan $\mathrm{Kj} 2$ sehingga tidak 
perlu disemprot dengan pembasmi hama karena teryata hasilnya Produktivitasnya lebih tinggi Kj 2 $(857 \mathrm{~kg} / \mathrm{ha})$ dari pada yang disemprot pembasmi hama. Musuh alami di agro-ekosistem kapas merupakan agens hayati yang dapat dimanfaatkan untuk mengendalikan populasi serangga hama jika populasinya berkembang dengan baik. Populasi musuh alami dapat dikonservasi jika pada agroekosistem kapas tidak dilakukan penyemprotan insektisida [19].

\section{KESIMPULAN}

Galur kapas $\mathrm{Kj} 1$ dan $\mathrm{Kj} 2$ yang berasal dari varietas NIAB 999, berasal dari Pakistan, yang diradiasi dengan sinar gamma dosis $20 \mathrm{~Gy}$, mutan ini terbukti dapat beradaptasi dengan baik di beberapa lokasi di Indonesia.

Kedua galur galur mutan harapan kapas ini mempunyai umur panen yang genjah (110-120 hari). Penanaman galur $\mathrm{Kj} 1$ dan $\mathrm{Kj} 2$ tanpa insektisida dapat menghasilkan kapas berbiji lebih banyak bila dibandingkan dengan menggunakan insektisida

\section{UCAPAN TERIMA KASIH}

Tim peneliti kapas BATAN mengucapkan terima kasih kepada Departemen Pertanian Direktorat Jenderal Bina Produksi Perkebunan, Jakarta, yang telah mendanai uji daya hasil galurgalur mutan kapas $\mathrm{Kj} 1$ dan $\mathrm{Kj} 2$ pada tahun 2004 di NTB, dan uji multilokasi pada tahun 2005 dan 2006 sebanyak 6 kali, sehingga usulan pelepasan varietas kapas dari kedua galur ini dapat terlaksana. Ucapan terima kasih juga diucapkan kepada tim dari Balai Penelitian Tembakau dan Serat Malang yang telah banyak membantu dalam pengarahan dan pelaksanaan di lapangan.

\section{DAFTAR PUSTAKA}

1. Subiyakto. Teknologi Pengendalian Hama Berbasis Ekologi Dalam Mendukung Pengembangan Kapas. J. Litbang Pertanian. vol. 30, no. 3, pp. 81-86, 2011.

2. Siwi Sumartini, Emy Sulistyowati, Sri Mulyani, dan Abdurrakhman. Skrining
Galur Kapas (Gossypium hirsutum L.) Toleran Terhadap Kekeringan PEG6000 Pada Fase Kecambah. J. Littri, vol. 19, no. 3, pp. 139-146, 2013.

3. Lilik Harsanti. Pengamatan Sifat agronomi, mutu serat dan Hama Penyakit galur Galur Mutan Harapan Kapas (Gosspium hirsutrum L.). J. Ilm. Apl. Isot. dan radiasi, vol. 12, no. 2, pp. 123-132, 2016.

4. Dwi Adi Sunarto dan Nurindah. Peran Insektisida Botani Ekstrak Biji Mimba untuk Konservasi Musuh Alami dalam Pengelolaan Serangga Hama Kapas. $J$. Entomol. vol. 6, no. 1, p. 42-52, 2009.

5. Emy Sulistyowati, Siwi Sumartini, Abdurrakhman dan Sri Rustini. Perbaikan Varietas untuk Peningkatan Produktivitas dan Mutu serat. J. Littri, vol. 15. no. 2, pp. 66-76, 2009.

6. Statistik Perkebunan Indonesia Komoditas Kapas. Direktorat Jendral Perkebunan Kementrian Pertanian, 2014-2016, pp. 20, 2015.

7. International Atomic EnergyAgency. Manual on Mutation Breeding. FAO/IAEA, Vienna. Austria, 1977.

8. Anna Pick kiong Ling, Ying Chian Ung, Sobri Hussen, Abdul Rahim Harun, Atsusi Tanaka and Hase Yoshihiro. Morpohological and Biochemical Responses of Oryza sativa L. (kultival $M R$ 219) to Ion Beam Irradiation, J. of Zhenjiang University, SCIENCE B. vol. 4, no. 12, pp. 30-36, 2013.

9. Human S, Andreani , Sihono and W.M. Indriatama. Stability Test For Sorghum Mutant Lines Derived From Induced Mutations with Gamma-Ray Irradiation. Atom Indonesia, vol. 37, no. 3, pp. 102106, 2011.

10. Mugiono, Lilik Harsanti dan Azri Kusuma Dewi. Perbaikan Padi Varietas Cisantana dengan Mutasi Induksi, J. Ap. Isot. dan Radiasi, vol. 5, no. 2, pp. 194-210, 2009. 
11. Saeed Rauf, Hafeez-ur-Rahman and Tariq Manzoor Khan. Effect of kinetin on multiple shoot induction in cotton. (Gossypium hirsutum L.) cv. NIAB-999. Iranian J. of Biotecnology, vol. 2, no. 4, pp. 279-282, 2004.

12. Hasnam, E Sulistyowati, S Sumartini, F.T Kadarwati dan P.D Riajaya. Kemajuan Genetik pada Dua Varietas Baru Kapas, Kanesia 8 dan Kanesia 9. J. Penelitian Tanaman Industri, vol. 10, no. 2, pp. 6673, 2004.

13. Emy Sulistyowati. Strategi Perbaikan Varietas Kapas Untuk Menghadapai Perubahan Iklim Global. J. Tanaman Industri. vol. 10, no. 2, pp. 58-69, 2011.

14. Igaa Indrayanii, deciyanto Soetopo. Efeektivitas formula Jamur Beauveria Bassiana Dalam Pengendalian Hama Penggerek Buah Kapas (Helicoverpa armigera). J. Littri, vol. 19, no. 4, pp. 178-185, 2013.

15. Nurindah. Peranan Parasitoid dan Predator dalam Pengendalian Wereng Kapas amrasca biguttula (Ishida) (Heteroptera:
Ciccadellidae). J. Perspektif, vol. 11, no. 1, pp. 23-32, 2012.

16. Evangeslista.JR. R.L.Santos J.B Torres and Jc Zanucio. Effect of gossypol on survival andreproduction og the zooophytophagous stinkbug podisus nigispinus (Dallas). Revista Brasileira de Entomogogioa, vol. 55, no. 2, pp. 267-271, 2011.

17. Holeay,, David, D, Lori Lach Andrew V. Suarez, Neil D, Tsutsui, Ted J. Case. The causes and consequences of ant invasions. Ann. Rev. Ecol. Syst., vol. 33, pp. 181-233, 2002.

18. Efrem Bechere, Rick B Turley, Dick L. Auld, Linghe Zeng. A New Fuzzless Seed locus in an Upland Cotton (Gossypium hirsutum L.) Mutan. American J. of Plant Sciences, vol. 3, pp. 799-804 2012.

19. Igaa Indrayanii, Prabowo Heri, Sumartini Siwi. Efektivitas dan Efidiensi Beberapa Teknik Pengendalain Hama Pengisap Daun pada Kapas. J. Penelitian Tanaman Industri, vol. 18, no 2, pp.4753, 2012. 